\title{
Value Comparison of Chinese Household Paper Industry
}

\author{
Wang Tao \\ School of Economics and Management, Xidian University, China \\ Zhong Yue* \\ School of Economics and Management, Xidian University, China
}

\begin{abstract}
China's household paper industry saw steady growth in 2017 as the country's economy stabilized and improved, while benefiting from increased population urbanization and consumption upgrading. On the other hand, under the circumstance of strict environmental protection and high fluctuation of external pulp price, the speed of capacity clearance is accelerating, thus driving the market share closer to the leading position. This Paper analyzes the assets and business performance of three companies, Hengan International Group Co. Ltd, Vinda International Holdings Limited and C\&S Paper Co. Ltd, which are the first tier in Chinese household Paper industry. It is concluded that Hengan, as the industry leader, has a large volume and is now in a stable position. Vinda also has diversified development, but the situation is not objective. As a rising star, C\&S focuses on living paper. Though it is small in size, it is growing rapidly, and has already surpassed Vinda.
\end{abstract}

Keywords: Differentiation; E-commerce; Excess production capacity; Marketing channel; High-end oriented.

(9) (i) CC BY: Creative Commons Attribution License 4.0

\section{Introduction}

The reason for the rapid growth of domestic paper demand in China in recent years is mainly due to the stable development of China's economy. In addition, paper products have been continuously subdivided into different application scenarios, expanding the demand space. The three major brands of Chinese household paper have been focusing on the consumption trend, constantly improving the product quality to reflect the differentiation, and actively expanding the marketing channels to drive the business performance. In the existing literature analysis, scholars pay more attention to the overall operation of the household paper industry and their prospects for the future market.

Hao (2011) sorted out the investment and construction of the paper industry in 2010, taking stock of the completion, production and construction of pulping, cultural paper, wrapping paper and household paper, indicating that the construction of large advanced paper machines of various paper types promoted the pace of industrial upgrading. The development of household paper has become a highlight in 2010. The construction of advanced household paper projects in various regions may trigger a blowout of the household paper market that lags behind the development of the national economy. In addition, it also analyzed the merger and reorganization event of paper industry, further explained that the rapid merger and reorganization of traditional paper giants, central enterprises, and foreign capital, as well as the newly-built and expanded production, made the market of China paper industry more active and improved the concentration degree of China's paper industry. Jessica (2013) analyzed the operation of China's paper industry in 2013.He found that the industry was at the stage of overcapacity and put forward corresponding solutions. Wang (2016) for living in the era of "Internet +" marketing channel to make a research paper, the analysis of the age of the Internet daily paper marketing development potential, on the basis of marketing channel to make use of the Internet technology innovation, and put forward to build life paper $\mathrm{O} 2 \mathrm{O}$ threedimensional network marketing model, perfect life paper marketing database, use the Internet for daily paper brand promotion and attaches great importance to the talent training of four innovation path. Zhou (2017) systematically outlined China's household paper industry in 2016.She described the size of the market, product structure and marketing. It also forecasts future developments. Wu (2018) first analyzed the impact of the rising commodity pulp price on the global pulp and paper industry, predicted the potential of the Chinese market, and finally analyzed the impact of important events in the paper industry in 2017 on the paper industry and the guiding role of China's macro policies on the industry.

\section{Analysis of Chinese Household Paper Industry}

\subsection{Domestic Paper Supply in China}

With the development of China's economy, China's paper industry reached the peak of industry prosperity in 2010. The high profitability of the industry attracted large number of medium and small capacity to enter, and then the industry entered the period of excess capacity. In 2014, the paper industry bottomed out, with the first negative profit growth in nearly a decade (down $1.44 \%$ year on year). After that, the industry entered a reshuffle period, under the dual role of government policies and market competition, medium and small capacity gradually withdrew. At present, the paper industry has entered the transition period from growth to maturity and is in the process of 
restructuring, upgrading and seeking a new balance. Pollution control, elimination of backward production capacity is the main direction of the industry development. At present, the backward production capacity of the industry accounts for about $30 \%-40 \%$ of the overall production capacity, mainly in the paper products industry with low industrial concentration such as cultural paper and household paper, mostly in small towns and small rural enterprises.

In terms of cost, household paper is usually made from wood pulp, bamboo pulp, bagasse pulp, grass pulp and waste paper pulp. Leading enterprises of high-end household paper, such as Hengan, Vinda, and C\&S, have adopted $100 \%$ raw wood pulp to make household paper. Wood pulp has become the main raw material of living paper. As China's papermaking raw material structure is dominated by non-wood fiber for a long time, wood pulp and highgrade pulp are in serious shortage, and the import dependence is as high as $90 \%$. The raw materials for first-line enterprises are basically imported, mainly from Canada, Brazil, Chile, Russia and other countries. The cost of wood pulp accounts for $60 \%$ of the total cost of household paper, so the production capacity of foreign wood pulp will greatly affect the domestic wood pulp price. In early 2016, due to the sluggish paper market, the price of wood pulp fell all the way down. Until September, the demand for raw materials of downstream paper enterprises was gradually exuberant, and the supply of wood pulp for commodities on the market was tight. Then in 2017 there was a shortage of supply due to an increase in supply chain accidents. Since the second half of 2017 , the price of wood pulp has been rising continuously, up to 50\%, which has brought great cost pressure to the whole household paper industry, and to some extent forced small and medium-sized production capacity to clear.

\subsection{Domestic Paper Demand in China}

In China's consumer goods market, the future of living paper is a huge potential industry, the current per capita consumption of paper is slightly lower than the global average. The background of consumption upgrade, population urbanization and economic growth has brought tremendous impetus to the sustained growth of household paper industry. Global consumption of household paper grew no more than 4 per cent a year from 2011 to 2015, according to global household paper industry data released by RISI consultancy. The annual growth rate of China's household paper consumption is not lower than 6.6 percent. China is the market with the highest growth rate of household paper consumption in all major regions of the world. The annual per capita consumption of household paper in mainland China was only $5.2 \mathrm{~kg}$ in 2015 , a huge gap compared with developed countries Sweden (24.0 kg/year), the United States (21.9 kg/year) and South Korea (19.7 kg/year). Household paper has the attributes of consumer goods, and residents' demand for it is closely related to their economic level. With the improvement of national economic level, people's demand for medium and high-end household paper has increased sharply for meeting their health, daily cleaning and other needs. In 2016, the consumption of toilet paper for toilet use reached 4.81 million tons, and the proportion of sanitary roll paper decreased from $67 \%$ in 2009 to $56.3 \%$ year by year. Correspondingly, the consumption category of facial tissue paper and kitchen paper also increased most significantly with the change of people's living habits. In 2009, facial tissue paper and kitchen paper accounted for $14.0 \%$ and $0.3 \%$ of the total consumption of household paper respectively. By 16 years, tissue paper and kitchen paper had reached 26.2 percent and 1.3 percent respectively.

\subsection{Competition Situation of Domestic Paper Industry}

The current China's household paper industry structure is more dispersed, the domestic market according to the production has three tiers: the first tier for domestic four leading enterprises in Hengan, Vinda, Gold Hongye Paper, C\&S, annual output over 150000 tons, scale and brand advantages, through the national production base and sales network set up layout, participate in the competition of the national market. The second and third echelons are composed of enterprises with annual output of less than 15 tons, all of which are regional manufacturers, taking midrange products or price wars as the main means to participate in regional market competition.

In the top tier of household paper industry, the gross profit rate is above $30 \%$. Hengan international and Vida international involve two major businesses of household paper and personal care. The proportion of Vida international personal care business is increasing year by year. From the perspective of the four major brands in the industry, Hengan started its business with "anle" sanitary products, gradually formed three product lines of feminine hygiene products, household paper and diapers, and constantly developed new product series. It owns xinxiangyin, pinnuo, and preferred, and its main brand is xinxiangyin. Vinda precisely grasps the consumers' pursuit of paper quality. Its brands are Vinda, debao and so on, focusing on Vida. Currently, it mainly develops four major businesses, namely, household paper, incontinence care, female care and baby care, with 11 brands. Gold Hongye owns three major brands of qingfeng, weijieya and zhenzhen. Qingfeng, as the main brand, also establishes a strong competitive position in the industry with its cost-effective products and affinity brand marketing. Its products are mainly toilet paper, facial tissue paper, kitchen paper and wet towel paper. The product positioning of $C \& S$ is differentiated and high-end, covering a variety of high-end paper, especially the FACE series and LOTION series, which are favored by consumers due to its unique selling points and excellent product quality. In terms of brand positioning, Hengan, Vinda and Gold Hongye are all featured by mid-range level of brand positioning, while C\&S is featured by brand jairou in mid-range and high-end. Compared with $C \& S$ and Hengan, $C \& S$ has strong advantages in e-commerce channels. Compared with $C \& S$ and Gold Hongye, $C \& S$ has a strong profitability as it has a strong first-mover advantage in medium and high-end products. According to the Chinese household paper almanac data, the domestic household paper market in China was 98.8 billion yuan in 2016. Based on the annual reports of the companies, the market share of Hengan, Vinda and Gold Hongye in 2016 was calculated to be 9.2\%, 9.1\% and 9.9\% respectively. The market share of C\&S was the smallest, at 3.9\%. However, since 2014, the development has been 
rapid and the market share has been continuously increased. In comparison, the market share of Hengan and Gold Hongye decreased slightly in 2014-2016.

Household paper tends to be more consumer oriented, and its price sensitivity is weak. Enterprises are the most critical to channel interception and control. Generally speaking, brand and operation are the main core competitiveness and barriers of enterprises, and the driving force of industry income growth mainly comes from the expansion of channels and the increase of the share brought by brand competitiveness.

\section{Analysis of Paper Enterprise Value \\ 3.1. Analysis of Marketing Channels}

For daily consumer goods such as household paper, the penetration of channels is an important basis for enterprises to open profit space. Household paper is mainly through the offline channels, namely the store, supermarket and convenience store. At the same time, with the rapid rise of e-commerce shopping in recent years, the e-commerce channel share of household paper sales has been steadily increased, and the business income of major brands on e-commerce platforms such as Tmall and Jingdong has also become an important source of income.

As the largest leading enterprise, Hengan has greatly improved its competitiveness by comprehensively grasping multi-channel sales channels and attaching great importance to the improvement of sales system. More than 10 years ago, the continuous innovation of flattening, differentiating and widening of sales channels began. The coverage of over a million sales outlets and products throughout the domestic and international market has become the core competitiveness of Hengan as a leading brand in the household paper industry. The advantage of multiple sales channels is also reflected in the diversity of the group's products. Different commodities have Shared resources with each other, improved the effective utilization rate of the channel, and the comprehensive popularity and influence of the brand have also been enhanced.

The commercial pathway of Vinda is the most successful. As early as 1993, with its high-quality paper products, Vinda became the largest paper supplier of the world's first fast food chain in China. At present, all kinds of paper products have entered thousands of hotels, institutions, office buildings and other places, sitting firmly on the top of the commercial paper chair. In the future, the company will continue to make efforts in commercial channels and continue to enter star-rated hotels and other commercial places.

$\mathrm{C} \& \mathrm{~S}$ constantly improves the management and construction of marketing channels. On the one hand, it increases exploration and deep cultivation of offline channels; on the other hand, it optimizes and integrates online channels to realize interactive sales of online and offline products. At the same time, through the constant upgrading of products and the introduction of new products, we can meet the diversified demands of consumers, further strengthen and consolidate brand strength, and achieve the national coverage of products. Since the introduction of a new marketing team in 2015, the marketing channels have been fully developed, and the company's sales outlets have been expanding and sinking. The marketing network covers most of the county-level cities in China, constantly subdividing and flattening the market and expanding the network layout of dealers. In addition, I also invested a lot in e-commerce platforms like Tmall, and strengthened and built corresponding supply chain system. The company has also set up a professional business sales service team to meet the growing business market demand.

\subsection{Assets Comparison}

C\&S has the smallest total assets and Hengan has the largest. Hengan was founded in 1989 and listed in 1998. It is one step ahead of C\&S and Vinda in the household paper hygiene products industry. C\&S and Vinda were both founded in 1999. However, from the comparison of asset size growth, the three enterprises all experienced a sharp slowdown in asset growth in 2015. Except for Vinda, Hengan and C\&S 's total assets were in a state of continuous decrease in 16 years, and their growth rate changed from negative to positive in 17 years, and their asset size expanded. This is due to the imbalance between supply and demand after the high profits of the industry in 2010 attracted large number of medium and small capacity to enter. Therefore, enterprises shrank their capacity in 2015 and 2016. With the impact of rising pulp price in 2016 and 2017, some small and medium-sized enterprises withdrew from competition, so enterprises started to expand their production in succession.

Table-1. Comparison of Assets in 2013-2017

\begin{tabular}{|c|c|c|c|c|c|}
\hline & 2013 & 2014 & 2015 & 2016 & 2017 \\
\hline \multicolumn{6}{|c|}{ Hengan } \\
\hline Ratio of current assets to total assets (\%) & 67.98 & 67.42 & 65.66 & 64.80 & 65.99 \\
\hline Where: Ratio of monetary capital to current assets (\%) & 71.61 & 74.19 & 68.93 & 67.22 & 71.80 \\
\hline Ratio of accounts receivable to current assets (\%) & 8.00 & 8.55 & 10.28 & 12.40 & 9.01 \\
\hline Ratio of inventories to current assets (\%) & 16.05 & 12.87 & 15.28 & 14.44 & 13.38 \\
\hline Receivable Turnover & & & 9.59 & 7.15 & 7.84 \\
\hline \multirow{2}{*}{\multicolumn{6}{|c|}{ 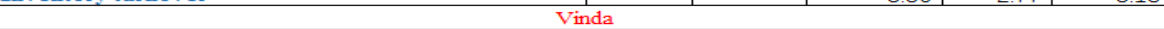 }} \\
\hline & & & & & \\
\hline Ratio of current assets to total assets (\%) & 39.08 & 35.53 & 34.30 & 31.00 & 31.21 \\
\hline Where: Ratio of monetary capital to current assets (\%) & 18.83 & 16.61 & 9.17 & 20.95 & 9.03 \\
\hline Ratio of accounts receivable to current assets (\%) & 24.91 & 26.75 & 25.67 & 34.40 & 31.37 \\
\hline Ratio of inventories to current assets (\%) & 44.85 & 46.80 & 55.20 & 36.84 & 51.48 \\
\hline Receivable Turnover & & & 8.58 & 8.71 & 7.65 \\
\hline Inventory turnover & & & 3.06 & 3.97 & 3.93 \\
\hline \multicolumn{6}{|c|}{ C\&S } \\
\hline Ratio of current assets to total assets (\%) & 48.24 & 43.44 & 44.47 & 45.96 & 52.04 \\
\hline Where: Ratio of monetary capital to current assets (\%) & 45.85 & 33.47 & 33.90 & 46.25 & 36.02 \\
\hline Ratio of accounts receivable to current assets (\%) & 15.47 & 17.15 & 21.42 & 26.05 & 19.86 \\
\hline Ratio of inventories to current assets (\%) & 27.78 & 31.93 & 35.81 & 20.31 & 18.15 \\
\hline Receivable Turnover & & & 7.64 & 7.80 & 8.14 \\
\hline Inventory turnover & & & 2.96 & 4.25 & 6.24 \\
\hline
\end{tabular}

Source: From the company's annual report calculation collated 
From 13 to 17 years, Hengan is the highest proportion of current assets to total assets of the enterprise. Further analysis of the current assets, Hengan has a lot of money, it flush with cash, but too much cash may lead to capital utilization rate is not high. Accounts receivable accounted for the least proportion of current assets compared with the three enterprises. As the industry leader, accounts receivable can be kept low, which shows that they have excellent performance in terms of sales mode and collection. Its inventory is also relatively stable, accounting for the smallest proportion of current assets. The proportion of C\&S liquid assets in total assets is relatively average, and the structure is relatively balanced. The accounts receivable is higher than Hengan but lower than Vinda, and the inventory level is also in the medium level. Vinda, relatively illiquid assets accounted for the proportion of total assets is larger. In the past five years, the proportion of monetary capital was relatively small, and in two years it was less than $10 \%$. Receivables account for a relatively large proportion of current assets, and inventory accounts for the largest proportion, taking up most of the funds, and there may be the problem of overstocked goods. The actual payment capacity and liquidity of enterprises are relatively poor, and the liquidity of assets is also relatively poor.

Comparing the receivables turnover of the enterprise, Hengan slightly improved after the decline trend; However, Vinda experienced a decline after slow growth, which showed that the payment days of credit sales had been extended in recent years, resulting in certain sales pressure. $C \& S$ is rising steadily, indicating that its average collection period is shortened, asset flow is accelerated and solvency is strengthened.

At the same time, by observing the inventory turnover rate in the last three years from 15 to 17 years, it can be found that the inventory turnover rate of C\&S increases year by year with a large margin, which is due to the expansion of sales channels and continuous subsidence, which improves the company's liquidity. While the inventory turnover of Hengan started to decline from 15 years, although it improved in 2017, it was the slowest turnover among the three enterprises in the following two years. The inventory turnover of Vinda was essentially unchanged for 17 years after a slight rise in 15 years. Through comparison of the growth rate of the operating income of the three enterprises, we can also understand the change. In the past three years, the operating income of C\&S increased rapidly from $17.34 \%$ to $28.74 \%$ to $21.76 \%$. Therefore, it is bound to accelerate the turnover of inventory. The operating income of Hengan is not strong in the first three years and even shows a downward trend, with the growth rate of $2.60 \%,-21.16 \%$ and $2.84 \%$ in the last three years. Therefore, its inventory turnover will also slow down. Vinda's revenue growth in the past three years was $21.41 \%, 24.35 \%$ and $11.86 \%$.

\subsection{Business Comparison}

Compared with the operating income of the three enterprises, C\&S started late, but has a strong momentum and obvious growth. Although Hengan's revenue growth slows down or even decreases, it is still second to none in terms of total operating income. After all, Hengan is in the leading position in the industry, and it starts early and has a wide range of business.

From 2013 to 2016, Hengan international income growth declined significantly, while C\&S and Vinda income growth increased in the opposite direction. The differentiation of distinct income growth reflects the impact of product structure and sales channel structure on the income growth of living paper enterprises. From product structure, in addition to the sales volume factor, the continuous increase in the income growth of C\&S is more about the promotion of the middle and high-end categories to push up the consumer price band. Corresponding to the period 2014-2016, C\&S in the soft roll and the non-roll of paper sales tons price does not appear significant signs of price increases, there are even caused by pulp price downward price behavior, thus the product structure of high-end drive for profitability. From the perspective of channel structure, C\&S and Vinda are significantly better than Hengan in the exploration of e-commerce channels. In 2017, the proportion of e-commerce income of C\&S has increased to $13 \%$, and that of vinda is nearly $20 \%$, while that of Hengan is only $8.8 \%$. This shows although Hengan has millions of sales outlets offline, with the change of consumer behavior, the weakness of living paper enterprises online will still become the constraint of future income growth. Further analysis of the three companies gross margin level, it can be directly found that gross profit margin of Hengan is much higher than the Vinda and C\&S, nearly three years in more than $46 \%$ of a high level, on the one hand, the main female hygiene products gross profit margin is much higher than life paper, secondly diversified business of scale effect will also enhance the level of gross margin. The gross profit margin of C\&S is slightly higher than Vinda at over $32 \%$.

\subsection{Comparison of Management Level}

Compared with the expense ratio of the three enterprises in the period from 2013 to 2017, the difference is not large, which is about $25 \%$. Except for the rapid increase of the expense ratio of Vinda in the period from 2013 to 2015, the changes are relatively stable, indicating that the management and control system of the enterprises are all good.

It is worth mentioning that the product innovation of C\&S is the most outstanding one of the four domestic paper enterprises in China. C\&S first introduced three-ply toilet paper 2,000 years ago. Around 2000, it boldly innovated in order to make it more convenient for consumers to carry, roll toilet paper packaging. In 2002, it bold use of orange packaging, red packaging, a sweep of those dull packaging colors. After 2004, it successively introduced the most flexible cosmetic paper, wet handkerchief paper, more mini handkerchief paper. The investment in research and development in 2017 includes the recently popular natural wood series. In the way of product innovation, it has made great contribution to the industry.s 


\subsection{Financial Comparison}

Table-2. Comparison of Financial Levels in 2015-2017

\begin{tabular}{|c|c|c|c|c|c|c|c|c|c|}
\hline \multicolumn{2}{|c|}{} & Current ratio & Quick ratio & $\begin{array}{c}\text { Asse-liability } \\
\text { ratio(\%) }\end{array}$ & $\begin{array}{c}\text { Net profit } \\
\text { margin(\%) }\end{array}$ & $\begin{array}{c}\text { Main business } \\
\text { profitability(\%) }\end{array}$ & $\begin{array}{c}\text { Return on total } \\
\text { assets(\%) }\end{array}$ & $\begin{array}{c}\text { Return on } \\
\text { equity(\%) }\end{array}$ & $\begin{array}{c}\text { Earnings } \\
\text { per share }\end{array}$ \\
\hline \multirow{3}{*}{ Hengan } & 2015 & 1.22 & 1.03 & 54.40 & 16.78 & 23.49 & 9.91 & 23.11 & 3.31 \\
\cline { 2 - 11 } & 2016 & 1.45 & 1.24 & 56.77 & 19.51 & 23.65 & 9.81 & 22.37 & 2.97 \\
\cline { 2 - 11 } & 2017 & 1.34 & 1.16 & 57.98 & 19.18 & 25.02 & 10.39 & 24.61 & 3.15 \\
\hline \multirow{4}{*}{ Vinda a } & 2015 & 1.1 & 0.49 & 60.43 & 3.24 & 4.63 & 2.55 & 6.27 & 0.32 \\
\cline { 2 - 11 } & 2016 & 1.01 & 0.65 & 56.62 & 5.42 & 6.70 & 4.65 & 10.21 & 0.60 \\
\cline { 2 - 10 } & 2017 & 1.12 & 0.54 & 53.96 & 4.60 & 5.71 & 3.59 & 8.00 & 0.53 \\
\hline \multirow{3}{*}{ C\&S } & 2015 & 1.81 & 1.16 & 46.44 & 2.98 & 31.60 & 1.94 & 3.69 & 0.18 \\
\cline { 2 - 10 } & 2016 & 2.15 & 1.72 & 40.25 & 6.84 & 35.01 & 5.75 & 10.21 & 0.54 \\
\cline { 2 - 10 } & 2017 & 1.17 & 0.96 & 47.44 & 7.53 & 34.08 & 6.78 & 12.28 & 0.47 \\
\hline
\end{tabular}

Source: From the company's annual report calculation collated

The current ratio between 2015 and 2017 was observed, and combined with the quick ratio, it shows that the overall trend is the same. As the result of the bank borrowings in 2017, the liquidity and quick ratio of $\mathrm{C} \& \mathrm{~S}$ decreased, which was the second place. Previously, C\&S was the first place, with good short-term solvency. It is worth mentioning that the quick ratio of Vinda is significantly lower than its current ratio and is at the level of less than 1 , which indicates that its inventory is high and its short-term solvency is low.

The asset liability ratio of C\&S is the lowest; Hengan has an upward trend in the past three years; Vinda, on the other hand, is reducing its debt. It is worth emphasizing that under the circumstances of rapid growth of income and accelerated expansion of channels, $C \& S$ has achieved continuous optimization and improvement of the balance sheet structure, thus driving the decline of the asset-liability ratio. This fully shows that the company has strong endogenous growth strength and low dependence on external financing.

Analysis sales net interest rates can be seen that Hengan is far higher than C\&S and Vinda, While sales are much higher than others, costs remain relatively low this is because the product structure is different, Hengan sanitary napkin product ratio is high, the company's sales net profit margin is significantly higher than their peers, at the same time under the influence of pulp prices are relatively limited, so the company gross margin and net interest rate level is comparable companies more stable. The performance of C\&S has risen well in the past three years, surpassing the level of Vinda in 2016.

By comparing the profit margin of main business in 2015 and 2017, it shows that the profit level of main business of Vinda is the lowest. C\&S focuses on household paper, which contributes significantly to the profit creation of the enterprise, so the main business profit margin is the highest among the three enterprises.

The net interest rate of total assets can be seen Hengan highest, C\&S surpassed Vinda in 2016. The ROE of Hengan is also the highest. The rapid of rise in ROA of C\&S in recent years has led ROE to surpass Vinda. Hengan has the highest EPS for earnings per share, with Vinda slightly higher than C\&S.

\section{Discussion}

Based on Hengan, Vinda, C\&S in 2013 to 2017 of financial statement data, the line into the calculation and analysis, comparison of the current assets, operating performance and competition situation of three excellent enterprise in Chinese Household Paper Industry. The following three conclusions are drawn:

First, Hengan as the industry leader, a large size. For the original business has reached a bottleneck, development space has been limited, performance has declined. Enterprises have achieved diversified development. The status of the industry is relatively stable at present.

Second, Vinda also has diversified development, but the situation is not objective, the household paper business is not very bright, in recent years has been overtaken by $\mathrm{C} \& \mathrm{~S}$. At the same time, there is a squeeze in inventory, receivables turnover is slow, and the asset problem is relatively prominent.

Finally, although C\&S started late, its growth momentum is obvious. Its product differentiation and high-end development have been recognized by the market, and its market share has been seized rapidly. Its business performance is outstanding, and its asset condition is also excellent, and its development prospect is huge.

\section{Conclusion}

The domestic paper industry in China is in great demand at present and has great development space in the future. Meanwhile, the pressure on cost and environmental protection will lead to the clearing of small and mediumsized production capacity, and the industry concentration degree will be continuously improved. Keep optimistic about the growth value of China's top three leading enterprises in household paper. We put forward the following Suggestions to improve the daily operation of enterprises and seize market share:

First, make their products have differences, have unique quality advantages, be recognized by the market, enhance brand loyalty.

Second, pay attention to the construction of marketing channels, development both online and offline, acceleration of the refinement and sinking of marketing channels, and open up market space. 
Last, in the future, single household paper products will eventually reach the bottleneck. Enterprises should enhance customer stickiness, consider expanding business, realize diversified strategy and actively explore the market.

\section{References}

Hao, Y. (2011). 2010 paper industry inventory investment construction chapter. China Pulp \& Paper Industry, 3: 7480.

Jessica, H. (2013). Development trend of Chinese domestic paper industry there is a fear of overcapacity in Chinese domestic paper market in 2013. China Pulp \& Paper Industry, 5: 10-13.

Wang, H. (2016). Internet era life paper marketing channel innovation. China Pulp \& Paper Industry, 8: $29-31$.

$\mathrm{Wu}, \mathrm{Z}$. (2018). What is the major factor influencing China paper industry? Analysis on the development tendency of China and global pulp and paper industry. China Pulp \& Paper Industry, 9: 20-23.

Zhou, Y. (2017). Overview and prospect of Chinese household paper industry in 2016. China Paper Newsletter, 9: 50-59.

\section{Appendix 1}

The Accumulated Income and Profit of Paper and Paper Products Industry from 2010 to 2016

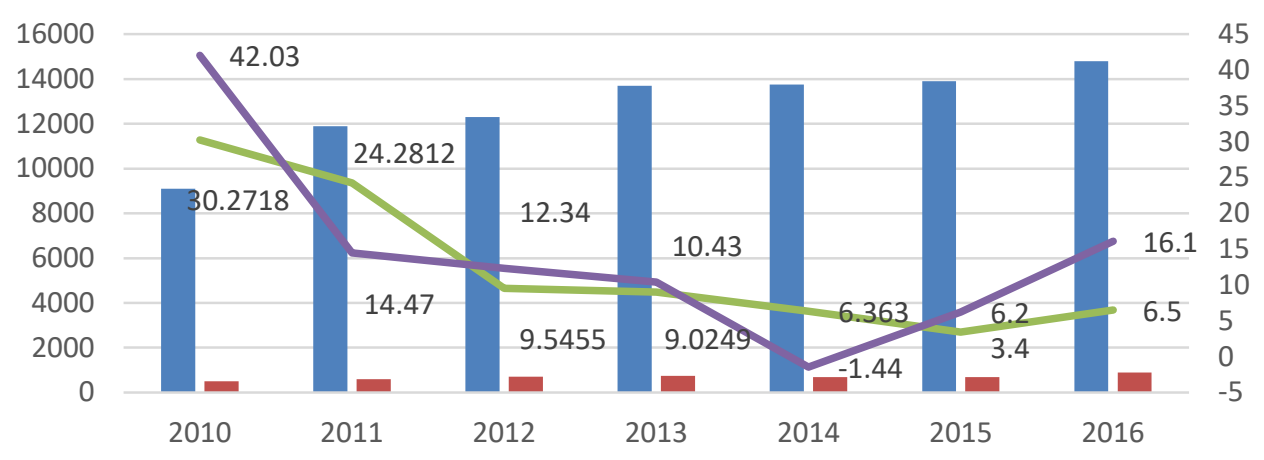

Cumulative revenue (RMB 100 million) Cumulative profit (RMB 100 million)

revenue growth rate (\%) — profit growth rate（\%)

\section{Appendix 2}

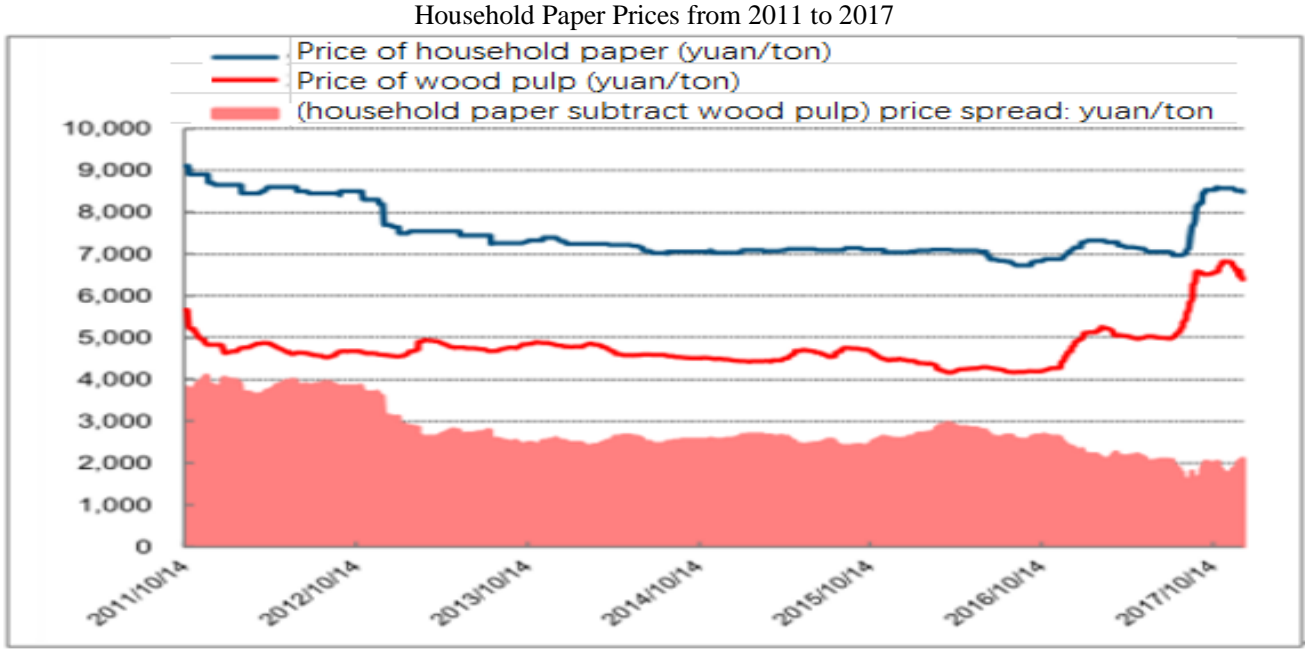

